\title{
DAILY ACTIVITY BUDGET OF BANDED LANGUR (Presbytis femoralis) IN MALAYSIA
}

\author{
MOHD FAUDZIR NAJMUDDIN ${ }^{1}$, HIDAYAH HARIS ${ }^{1}$, NORATIQAH NORAZLIMI ${ }^{1}$, BADRUL \\ MUNIR MD-ZAIN ${ }^{2}$, MOHD-RIDWAN ABD RAHMAN ${ }^{2,3}$, ROHANI SHAHROOL-ANUAR ${ }^{4}$, \\ ASIYAHTUL HUSNA HASSAN ${ }^{4}$ AND MUHAMMAD ABU BAKAR ABDUL-LATIFF*1
}

\begin{abstract}
${ }^{1}$ Centre of Research for Sustainable Uses of Natural Resources, Faculty of Applied Sciences and Technology, Universiti Tun Hussein Onn Malaysia (Pagoh campus), KM 1, Jalan Panchor, 84600 Muar, Johor, Malaysia. ${ }^{2}$ Department of Biological Science and Biotechnology, Faculty of Science and Technology, Universiti Kebangsaan Malaysia, 43600, Bangi, Selangor, Malaysia. ${ }^{3}$ Centre for Pre-University Studies, Universiti Malaysia Sarawak, 94300 Kota Samarahan, Sarawak, Malaysia. ${ }^{4}$ Panz village, Lot 147 Lorong Bahtera, Kg Johor Lama, 81940 Kota Tinggi, Johor, Malaysia
\end{abstract}

*Corresponding author: latiff@uthm.edu.my

Submitted final draft: 12 November 2019 Accepted: 21 December $2019 \quad$ http://doi.org/10.46754/jssm.2020.07.009

\begin{abstract}
Banded langur (Presbytis femoralis) is an endangered leaf-eating colobine, found in Johor and Pahang in Malaysia. However, with less than 500 individuals reported to be surviving in Johor, their behaviour and ecology remain unknown among primatologists. This study provides the first systematic data on the daily activity budget of the species in Malaysia. Scan sampling technique was used to observe and record $P$. femoralis behaviour with 10 min interval starting from February 2018 to November 2018. The results are based on $186 \mathrm{~h}$ and $20 \mathrm{~min}$ of direct observation in the wild. The animals spent most of the time for resting $(43 \pm 13 \%)$ followed by moving ( $26 \pm 9 \%$ ), feeding ( $26 \pm 7 \%$ ), social activities $(4 \pm 3 \%)$, and others $(1 \pm 0 \%)$. Seasonality significantly influences the activity budget of the animals resulting in increased resting and moving in the non-fruiting season. Feeding activities decreased in the non-fruiting season compared with the fruiting season, whereas social activities remained the same. We concluded that the daily activity budget of P. femoralis in this study portrays comparable behavior to other langurs in Malaysia that would help in conservation and management of the species in terms of understanding temporal and spatial requirements of P.femoralis in a highly fragmented habitat.
\end{abstract}

Keywords: Colobine, behaviour, conservation.

\section{Introduction}

Presbytis femoralis is an endangered Colobine (Primate) in Johor and can be found ranging in the southern part of Pahang and small population in Singapore (Md-Zain, 2004, Abdul-Latiff et al., 2019a). The population has been reported recently with fewer than 500 individuals in selected fragmented areas in Johor (Md-Zain et al., 2008; Vun et al., 2011; Abdul-Latiff et al., 2019a; Najmuddin et al., 2020b). AbdulLatiff et al. (2019a) recognizes the species as Schlegel's banded langur, Presbytis neglectus, based on molecular systematic approach. Having in mind the confusing and contradictory taxonomy, systematic relationships of $P$. femoralis femoralis, $P$. femoralis percura and $P$. femoralis robinsoni, Abdul-Latiff et al. (2019a) hypothesised that banded langur does not fit in the same species classification as P.f. robinsoni and P.f. percura as proposed by Groves (2001). Absence of comprehensive and reliable data for both P.f. robinsoni and P.f. percura previously has restricted the distinction of both species at species level from P.f. femoralis. But with recent findings on the recognition of $P$. robinsoni as distinct species (Md-Zain et al., 2019b) and recognition of $P$. percura by Ang et al. (2020) as hypothesised by Abdul-Latiff et al. (2019a), the classification of P. femoralis for banded langur is accurate and no longer confusing for this species groups.

P. femoralis is physically slim and slender, covered in black fur at dorsal area and white patches at ventral area down to thigh with no white patches found at the tail area (Groves, 2001). Although normally found covered in black fur, recent discovery reported two brown morph individuals of P.femoralis found in Kota 

Tinggi (Najmuddin et al., 2020a). Generally, $P$. femoralis are herbivores but also consume fruits and seeds as well (Caton, 1990; Nijboer, 2006; Kirkpatrick, 2017). Based on preliminary study on the P.femoralis, it can forage up to 27 species of plants from 17 families in severely fragmented habitat in Johor (Najmuddin et al., 2019a). Abdul-Latiff et al. (2019b) in their preliminary study using ad libitum observation method had found the $P$. femoralis spending $36.85 \%$ of their activity budget resting, followed by moving $(35.65 \%)$ and feeding $(21.79 \%)$ (Abdul-Latiff et al., 2019b; 2019c). However, the issues facing banded langur are the rapidly decreasing population largely because of the threat of habitat fragmentation, land use change, habitat degradation, natural predator and also exploitation as bushmeat (Abdul-Latiff et al., 2019a; Md-Zain et al., 2019a; Najmuddin et $a l ., 2019 b)$. On top of these threats, much is unknown about $P$. femoralis in terms of its behaviour and ecology. Further information such as long-term behavioural data on daily activities, feeding ecology, and population assessment is considered the fundamental knowledge needed for the conservation and management purposes of this species.

Daily activity budget is the study of behaviour on the activities within one complete day (Rizzuto et al., 2017). The daily activity budget can help conservation efforts by giving an insight of temporal and spatial distribution of resources necessary for the animal to survive under threat of habitat loss and degradation (McCain \& King, 2014). The method for recording daily activities was established by Altman (1974) for studying animal behaviour and had been followed systematically for many animal behavioural studies (Altman, 1974; Matsuda et al., 2009; Long et al. 2010; Ruslin et al., 2014; Sha et al., 2018; Ruslin et al., 2019). The basic daily activities recorded are usually clustered into resting, feeding, moving, and others (Ruslin et al., 2014). Other behaviours are also recorded such as grooming, playing, vocalisation, mating, and fighting (Hambali et al., 2012; Siti-Kauthar et al., 2019). The importance of knowing the
P. femoralis behaviour is to assess population viability, dispersal and colonisation movement, human-primate conflict, and corridor uses (Reed, 2002; Abdul-Latiff et al., 2017a, 2017b). The knowledge can be further applied for translocation and reintroduction in conservation (Reed, 2002). Niko Tinbergen, a pioneer ethologist also proposed that the essences of behavioural study were to answer the four problems: causation, ontogeny, function, and evolution (Tinbergen, 1963).

The daily activity budget of colobines varies between species and habitat. Whether in wildlife reserve, national park, neighbouring human settlement, or totally disturbed habitat, colobines can be found living in that area and certainly allocate their budgets for daily activities differently. In Vietnam, an insular residence of Cat Ba Island National Park, the Cat Ba langur (Trachypithecus poliocephalus poliocephalus) spent $66 \%$ of its time resting, $11 \%$ moving, $15 \%$ foraging, and $8 \%$ for social activities (Schneider et al., 2010). Study on maroon langur, Presbytis rubicunda in intact forest in Sabangau, Kalimantan, Indonesia, showed annual activity budget comprised $48 \%$ resting, $29.3 \%$ feeding, $14.2 \%$ travelling, and $0.4 \%$ social behaviours (Smith et al., 2013). Mentawai islands sympatric, endemic colobines, Presbytis potenziani and Simias concolor were studied in 2012 and showed the domination of resting (45.7 and 49.8 events/h, respectively) behaviour followed by feeding ( 31.8 and 27.7 events/h, respectively), traveling ( 6.2 and 5.6 events/h, respectively), and other social behaviour ( 0.6 and 2.1 events/h, respectively) (Hadi et al., 2012). Thorough study on Nasalis larvartus in riverine forest of Kinabatangan, Sabah, Malaysia, showed that this odd-nosed colobine spent $76.5 \%$ of daily activity budget for resting, $19.5 \%$ for feeding, and $3.5 \%$ for moving (Matsuda et al., 2009). The result correlates with the large menu of $N$. larvatus of 188 species of plants in their diets that take time for fermentation and digestion (Matsuda et al., 2009).

Disturbed habitats such as urban landscape neighbouring with natural habitat do have 
effects on the primates. Cercopithecine longtailed macaque, Macaca fascicularis does alter its behaviour to disturbed habitat in Universiti Kebangsaan Malaysia, Bangi, Malaysia, but less likely for sympatric dusky leaf monkey, Trachypithecus obscurus (Ruslin et al., 2014). It was found that the $M$. fascicularis spent longer time feeding and moving than resting and other activities. However, T. obscurus spent much time in feeding and resting than moving. The leaf monkey was seen to fully utilise the natural habitat rather than longtailed macaques, which forage in neighbouring residential colleges (Ruslin et al., 2014). A study on the same species, T. obscurus in Penang Botanical Garden, a recreational park, resulted on daily activity budget dominated by feeding (40.02\%), resting $(23.96 \%)$, moving $(22.51 \%)$, autogrooming $(6.52 \%)$, vocalisation $(3.89 \%)$, allogrooming (1.33\%), allomothering $(0.97 \%)$, and playing $(0.80 \%)$ (Md-Zain \& Ch'ng, 2011). Most recently published study on T. obscurus in Penang Island showed that T. obscurus spent their time largely resting $(43.5 \%, \pm 3.8 \%)$; a quarter of their time feeding $(24.8 \%, \pm 4.8 \%)$ and locomoting $(24.4 \%, \pm 2.0 \%)$; and very small proportions of their time on social grooming $(3.8 \%, \pm 1.5 \%)$, social playing $(2.6 \%, \pm 1.5 \%)$, and foraging $(0.9 \%, \pm 0.3 \%)$ (Yap et al., 2019). Another study on urban population of Hanuman langur (Semnopithecus entellus) in India shows a majority of the activities is feeding (28.7\%) compared with its rural population where moving activity dominates $(33.7 \%)$ (Khatun et al., 2018). Such studies are important as basal knowledge for any primate species especially those under threat of habitat fragmentation. As of now for P. femoralis, unfortunately no systematic observation on its daily activity budget had been done. Thus, the aim for this paper was to describe the first systematic daily activity budget for P. femoralis in Malaysia.

\section{Methodology}

This study was conducted in Kota Tinggi, Johor, Malaysia. The study area setting has mangrove forest at river edges, oil palm plantation, fruit orchard, and abandoned rubber plantation with Malay village houses scattered around the village. The mean maximum and minimum temperature are $32^{\circ} \mathrm{C}$ and $24^{\circ} \mathrm{C}$, respectively (Othman \& Amin, 2018). Scan sampling (Altman, 1974) method was used for observation of daily activity budget of $P$. femoralis in the study area. There were two groups found ranging in the village. The group Dara was an all-male band of banded langur, which consisted of four identified members. Another banded langur group was named Bonda consisting of 12 individuals led by one alpha male, seven adults and sub-adult females, and four infants. The dusky leaf monkey group was also detected ranging in sympatry with long-tailed macaque (Macaca fascicularis) in the area. The observation focused on four individuals in all-male group Dara in the village that begun in February 2018 until November 2018. Observation started from 7:00 am and ended at 7:00 pm every sampling day. The sampling days for each month were fixed for 15 days.

Data for daily activity were recorded with interval of 10 min during observation, classified as feeding, resting, moving, socialising, and others. Feeding category is defined by foraging, manipulating, and ingesting the food material. Resting category is defined by inactive movement from a single place such as sleeping, sitting, and resting literally (Fruth \& McGrew, 1998). Moving category is defined by the movement from a single place to another location by any means such as jumping, crawling, walking, or climbing (Md-Zain et al. 2019a). Social activities such as vocalisation, playing, or mating are categorised under social category. Other than those mentioned, activities are being grouped in another category (Matsuda et al., 2009; Khatun et al., 2018). Daily activity budget was taken instantaneously by scan sampling (Altman, 1974).

Phenological record was based on phenological study by Sha et al. (2018) in Upper Seletar Reservoir, Singapore. Their study site is approximately $30 \mathrm{~km}$ from Kampung Johor 
Lama (Sha et al., 2018). From the study, three types of forest were assessed for phenological study; the one similar to our study site is short secondary forest. Thus, we referred to the fruiting season in the forest. We allocated January, February, March June, July, and August as the fruiting season, whereas September, October, November, December, April, and May as the non-fruiting season.

Budgets for each of the activities (moving, feeding, resting, and social) were calculated by obtaining the sum of the activity of each hour of observation (Long et al., 2010). ShapiroWilk test was used to test for data normality and advanced with Friedman test (IBM SPSS 22) (Allen et al., 2014) to find differences between the means of each activity against hours and months (Schneider et al., 2010). Data for other activities were excluded from analysis because of very small percentage of less than $1 \%$. All datasets were averaged by converting the total frequencies into percentage for further analysis. For analysis between seasons, we used ShapiroWilk test to test for normality. Then, we used independent $t$-test to see the significance between seasons as the data were determined to be normally distributed.

\section{Results}

\section{Activity budget}

The total sampling hours was $1236 \mathrm{~h}$, across 9 months of sampling. The total observation hours were $186 \mathrm{~h}$ and 20 min with mean hours per month at $20 \mathrm{~h} 42 \mathrm{~min}$ and $13 \mathrm{~s}$. The activity budget for the five major activities is shown in Figure 1.

There was a statistical difference between the time budgets for each different activityfeeding, resting, travelling, and socialising based on the Friedman test $\left(\mathrm{X}^{2}=30.581\right.$, df $=3$, $p<0.0001)$. Based on Figure 1, resting activity dominates the daily activity budget of banded langurs in Kampung Johor Lama by $43 \pm 13 \%$ followed by moving $(26 \pm 9 \%)$, feeding (26 $\pm 7 \%)$, social $(4 \pm 3 \%)$, and others $(1 \pm 0 \%)$. Box plot graph was developed in Figure 2 to

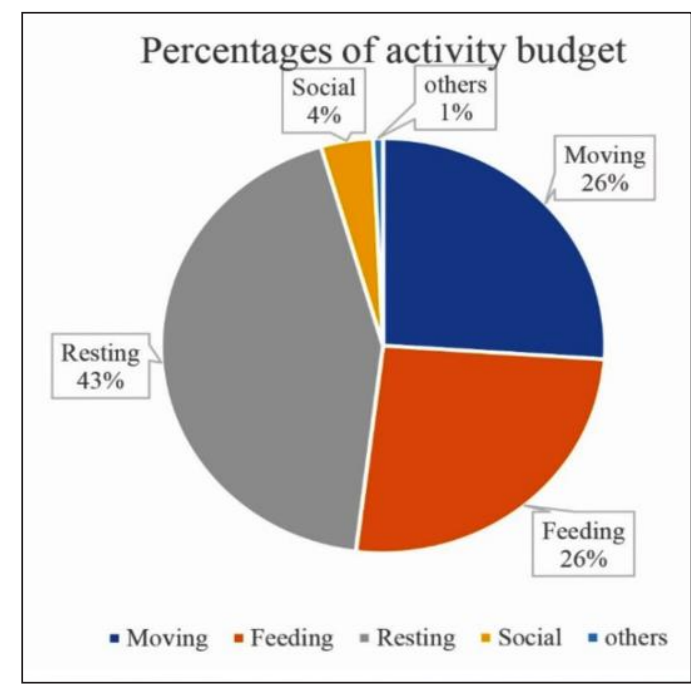

Figure 1: The overall activity budget of $P$. femoralis

evaluate the data distribution of each activity. The social activity was combined with others as the data was very small in percentages. Figure 3 shows the trend of each activity throughout the day with moving activity trend is fairly uniform during the day and decreased drastically toward mid-day between 12:00 p.m to 2:00 p.m and then increased back toward evening. Feeding activities are rather in uniform trend throughout the entire day with peaks in the morning and evening. The resting activities remained high in percentages with increasing trend starting from 9:00 a.m and reached its peak at 2:00 p.m and decreased toward evening at the lowest peak around 6:00 p.m. Social activities remained the lowest in percentages throughout the day and had quite a uniform trend.

\section{Variation of Activities between Seasons}

Both datasets of fruiting and non-fruiting seasons are normally distributed as the $p$-value more than 0.05 ( $\mathrm{df}=8$, fruiting season, $\alpha \geq 0.05$, non-fruiting season, $\alpha \geq 0.05$ ). The result from independent $\mathrm{t}$-test accepted the alternative hypothesis where the difference between fruiting season and non-fruiting seasons is statistically significant $(\mathrm{F}=7.774, p<0.05)$. The first comparison between seasons can be referred to in Figure 4 (a) for resting behaviour. Resting 


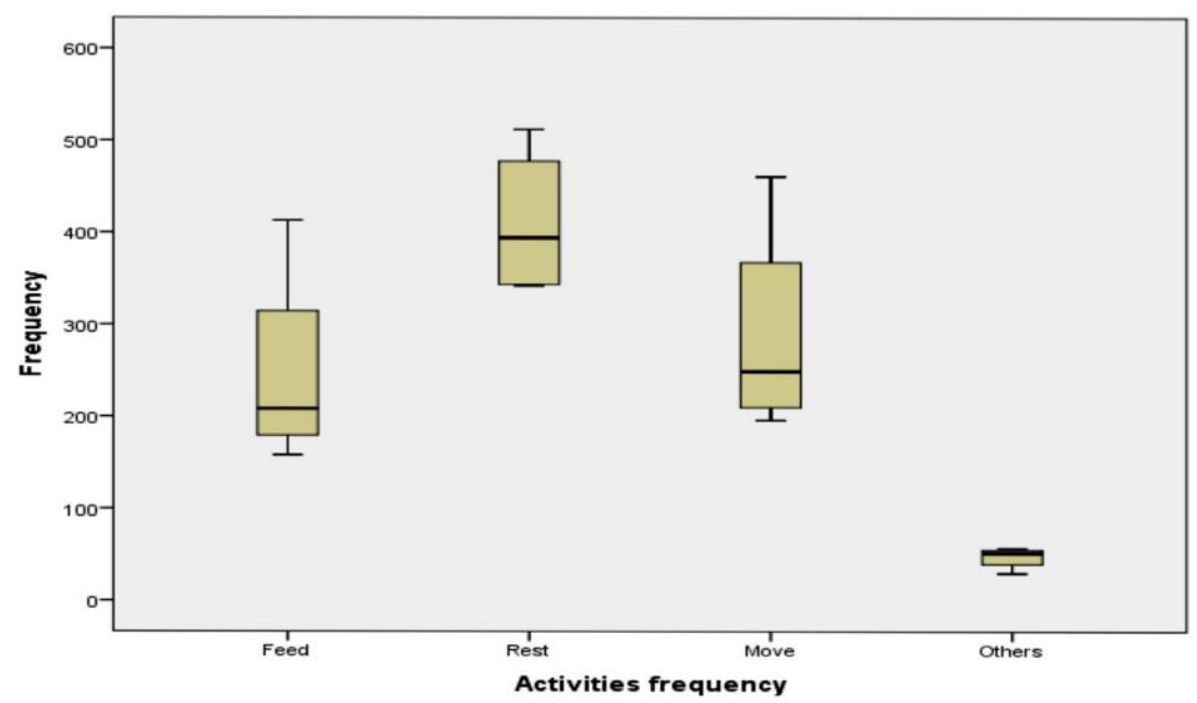

Figure 2: Box plot of the distribution of data for each activity

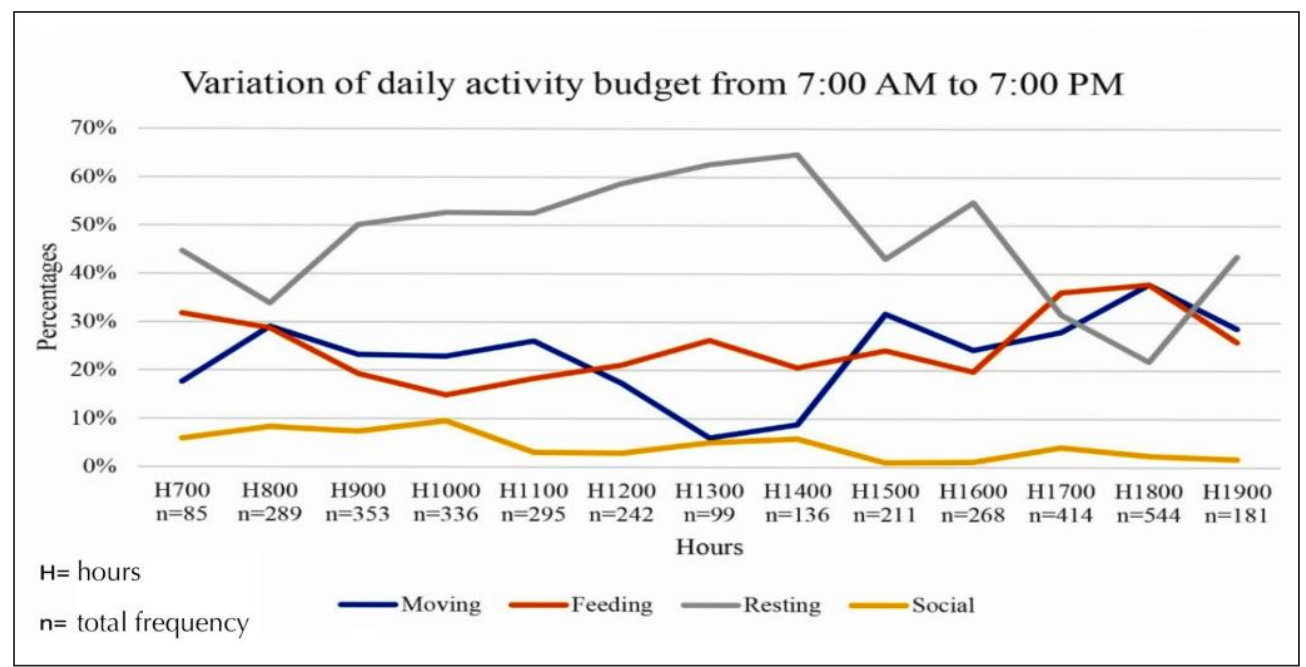

Figure 3: Variation of activity percentages over hours

behaviour shows uneven trends throughout the day for the non-fruiting season as the range varied from $21 \%$ to $81 \%$ as compared with the fruiting season with range varied from $19 \%$ to $65 \%$. Three peaks detected for resting hours in the non-fruiting season, which were at 9:00 a.m, 1:00 a.m and 7:00 p.m, whereas during the fruiting season, only a single peak was detected at 2:00 p.m. Overall, banded langur spent less time resting in the fruiting season $(42 \pm 13 \%)$ than in the non-fruiting season $(47 \pm 19 \%)$.
Based on Figure 4 (b), the trend of moving activities in the fruiting season was more even throughout the day, as compared with that in the non-fruiting season with several extremities at 1:00 p.m and 6:00 p.m. The range for the moving budget in fruiting season was $7 \%$ to $37 \%$, compared to non-fruiting season which was from $0 \%$ to $48 \%$ showing more evenness of moving activities in the fruiting season. Overall, moving activities during the fruiting season $(25 \pm 9 \%)$ was less than that for thenon-fruiting season $(28 \pm 15 \%)$. 
Feeding activities during the fruiting season was comparable with the non-fruiting season. The range of percentages of $15 \%$ to $44 \%$ for the fruiting season was compared with $67 \%$ to $11 \%$ for the non-fruiting season as can be seen in Figure 4 (c). The non-fruiting season had one extreme value at 7:00 a.m of $67 \%$ because of the low quality of food needed to be ingested early in the day. However, the highest percentage of feeding for the fruiting season (44\%) was at 6:00 p.m, perhaps for energy restoration before resting in the night. $P$. femoralis spent more time feeding in the fruiting season $(27 \pm 8 \%)$ than in the non-fruiting season $(20 \pm 15 \%)$.

Social activities remained small in percentage compared with other major activities (moving, feeding, and resting) as it only ranged from $1 \%$ to $11 \%$ for the fruiting season and $0 \%$ to $11 \%$ for the non-fruiting season. The trend of social activities of P. femoralis in both seasons is similarly even with peaks in the morning between $8: 00$ a.m to $10: 00$ a.m at $11 \%$ as can be seen in Figure 4 (d). The total overall activity percentage of social activities was equal for the fruiting season $(5 \pm 3 \%)$ and the non-fruiting season $(5 \pm 4 \%)$.

a)

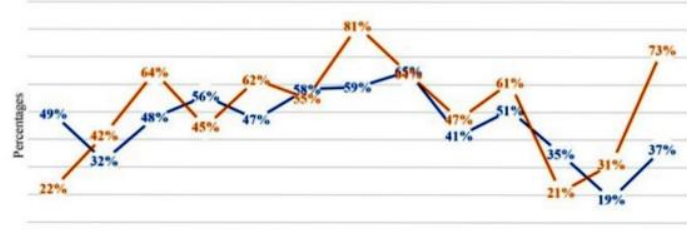

H700 Н800 Н900 H1000 H1100 Н1200 H1300 H1400 H1500 H1600 Н1700 Н1800 Н1900 Hours

\section{c) FEEDING}

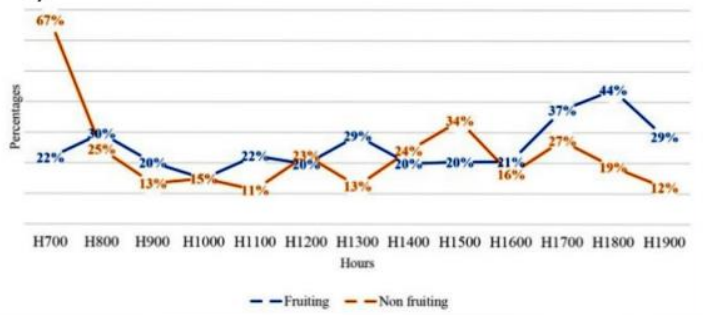

\section{Variation of Activities between Months}

Monthly variations in time budgets for different activities are presented in Figure 5. Budgets for major activities, such as feeding, resting, traveling, and social activities varied significantly between months $\left(x^{2}=13.584\right.$, $\mathrm{df}=3, p<0.05)$. The moving and resting activities trend throughout the months of observation are somehow unique to be explained. This can largely be attributed to difficulties in sighting of the population especially in February, April and May 2018. In February, the resting activity dominated the activity budget by $67 \%$ then dropped down to $13 \%$ and continued to rise again in July 2018 (45\%) and ended with peak on November 2018 (69\%). Conversely, the activity budget for moving was low in February $2018(0 \%)$ due to low sighting of the population (Figure 5) then rose and reached peak on May 2018 (73\%), after that the trend decreased month by month until November 2018 (14\%). For feeding activity, the trend is nearly even with a range from $9 \%$ to $38 \%$ and social activities are more even with only peak in February 2018 and decreased percentages month by month to finally reach 3\% in November 2018.

b) MOVING

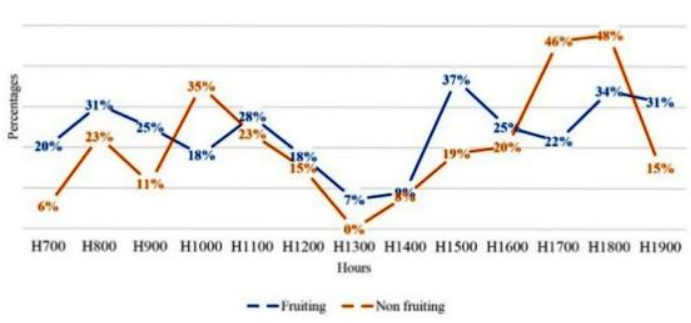

d) SOCIAL ACTIVITIES

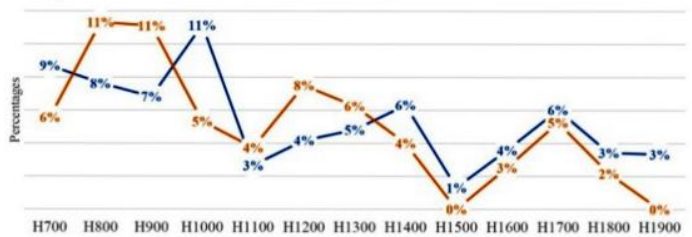
Hours

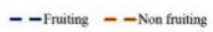

Figure 4: Seasonal difference of daily activities in fruiting and non-fruiting seasons ( $\mathrm{H}=$ hours) 


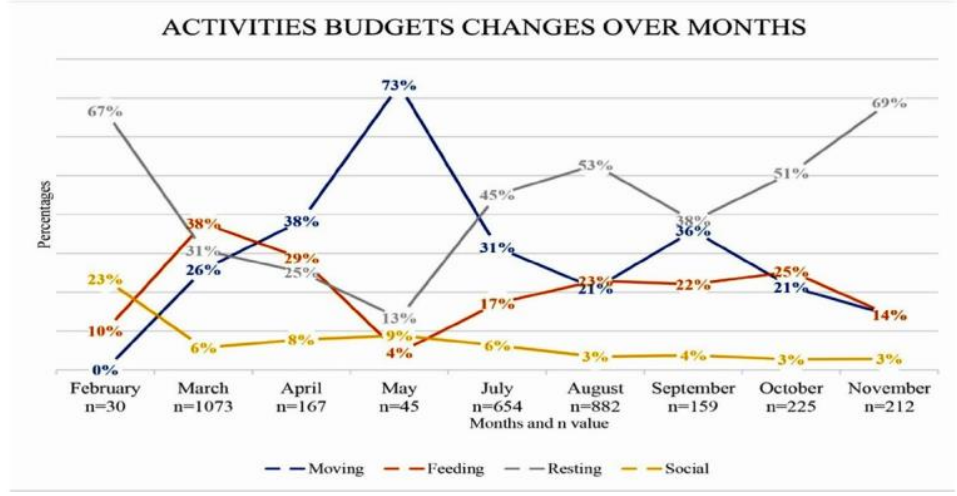

Figure 5: Monthly differences of daily activities from February 2018 to November 2018

\section{Discussion}

Based on our results of daily activity budget, resting time for $P$. femoralis dominated the daily activities budget $(43 \pm 13 \%)$. This proportion was also shown by other colobines such as $P$. rubicunda (48\%), $P$. potenziani (45.7 events/h), Pygathrix cinirea (37\%), S. concolor (49.8 events/h), and $N$. larvatus (76.5\%) based on Table 1 (Matsuda et al., 2009; Long et al., 2010; Hadi et al., 2012; Smith et $a l ., 2013)$. However, there are several species of colobines preferably different in terms of resting time allocation such as $R$. beiti in China (28.5\%), T. obscurus in Penang (23.96\%), and T. obscurus in Universiti Kebangsaan Malaysia (UKM) (38.1\%), ranking as the second largest budget of the daily activities (Grueter et al., 2013; MdZain \& Ch'ng, 2011; Ruslin et al., 2014). Resting time was hypothesised to be associated with the herbivory diet of langurs as they have tripartite stomach (Caton, 1999; Long et al., 2010). Thus, long resting time is associated with the fermentation of plant material in colobines' stomach even to an extent of 40 hours of particle mean retention time (Nijboer et al., 2007; Nijboer, 2006). However, Dasilva (1993) argued that diet is not directly related to resting time but is more closely related to weather condition. On top of the factors listed, other factors such as gut size, food passage rate, home range area, and the cost of locomotion are related to resting time and development of optimal foraging strategy (Garber, 1987).
Feeding is the most important activity in order for an animal to survive. Our results on feeding and moving behaviours show the same proportion, which is $26 \%$. Feeding activity is the second biggest proportion in other studies as well such as in $N$. larvatus, $P$. potenziani, $P$. rubicunda, S. entellus ajax, S. concolor, and T. p. poliocephalus (Matsuda et al., 2009; Minhas et al., 2010; Schneider et al., 2010; Hadi et al., 2012; Smiths et al., 2013). In contrast, other studies had found feeding to be the majority of the daily activity budget, as noted by Grueter et al. (2013) for R. beiti, Md-Zain \& Ch'ng, (2011) and Ruslin et al., (2014) for T. obscurus. Both studies by Md-Zain \& Ch'ng (2011) and Ruslin et al. (2014) had reported that dusky leaf monkeys (T. obscurus) in similar habitat allocate feeding behaviour as the majority of daily activities budget. Md-Zain \& Ch'ng (2011) explained that the spike of feeding behaviour was in December where young shoots began to sprout. Ruslin et al. (2014) explained that the large percentage of time that T. obscurus spent on feeding was during the evening before dusk, which is the same as in our study (Figure 3). It is perhaps the degraded habitat of Kota Tinggi (this study), Penang Botanical Garden (Md-Zain \& Ch'ng, 2011) and UKM (Ruslin et al., 2014) had forced langurs to forage in habitat with the presence of humans. Thus, feeding activity dominated their daily activity budget on feeding and no longer felt threatened by human presence. Since human settlement was also planted with fruiting trees, it might have attracted the langurs to forage near human settlement (Md-Zain \& Ch'ng, 2011). 


\begin{tabular}{|c|c|c|c|c|c|c|c|c|}
\hline \multirow{2}{*}{ No. } & \multirow{2}{*}{ Species } & \multirow{2}{*}{ Location } & \multirow{2}{*}{ Type of habitat } & \multicolumn{4}{|c|}{ Activities budget } & \multirow{2}{*}{ Reference } \\
\hline & & & & Resting & Feeding & Moving & $\begin{array}{l}\text { Social/ } \\
\text { others }\end{array}$ & \\
\hline 1 & Nasalis larvatus & Sabah, Malaysia & Natural riverine forest & $76.5 \%$ & $19.5 \%$ & $3.5 \%$ & $<1 \%$ & $\begin{array}{l}\text { Matsuda et al., } \\
2009\end{array}$ \\
\hline 2 & P. femoralis & Johor, Malaysia & $\begin{array}{l}\text { Disturbed secondary } \\
\text { forest }\end{array}$ & $43 \%$ & $26 \%$ & $26 \%$ & $5 \%$ & This study \\
\hline 3 & P. rubicunda & $\begin{array}{l}\text { Kalimantan, } \\
\text { Indonesia }\end{array}$ & Lowland intact rainforest & $48 \%$ & $29.3 \%$ & $14 \%$ & $0.4 \%$ & $\begin{array}{l}\text { Smith et al., } \\
2013\end{array}$ \\
\hline 4 & P. potenziani & $\begin{array}{l}\text { Mentawai island, } \\
\text { Indonesia } \\
\text { Kon Ka Kinh }\end{array}$ & Undisturbed mixed forest & $\begin{array}{l}45.7 \\
\text { events/h }\end{array}$ & $\begin{array}{l}31.8 \\
\text { events/h }\end{array}$ & $\begin{array}{l}6.2 \\
\text { events/h }\end{array}$ & $\begin{array}{l}0.6 \\
\text { events/h }\end{array}$ & $\begin{array}{l}\text { Hadi et al., } \\
2012 \\
\text { Long et al. }\end{array}$ \\
\hline 5 & P. cinerea & $\begin{array}{l}\text { National Park, } \\
\text { Vietnam }\end{array}$ & Forest Reserve & $37.0 \%$ & $11.9 \%$ & $25.8 \%$ & $25.1 \%$ & 2010 \\
\hline 6 & R. bieti & $\begin{array}{l}\text { Samage Forest, } \\
\text { China }\end{array}$ & Sub-tropical forest reserve & $28.5 \%$ & $38.5 \%$ & $19.1 \%$ & $13.9 \%$ & $\begin{array}{l}\text { Grueter et al., } \\
2013\end{array}$ \\
\hline 7 & S. e. ajax & $\begin{array}{l}\text { Machiara National } \\
\text { Park, Pakistan }\end{array}$ & $\begin{array}{l}\text { Temperate Himalayan } \\
\text { forest, livestock }\end{array}$ & $43.83 \%$ & $31.71 \%$ & $12.43 \%$ & $12.03 \%$ & $\begin{array}{l}\text { Minhas et al., } \\
\text { 2010; Dar et } \\
\text { al., } 2012\end{array}$ \\
\hline 8 & S. concolor & $\begin{array}{l}\text { Mentawai island, } \\
\text { Indonesia }\end{array}$ & Undisturbed mixed forest & $\begin{array}{l}49.8 \\
\text { events/h }\end{array}$ & $\begin{array}{l}27.7 \\
\text { events/h }\end{array}$ & $\begin{array}{l}5.6 \\
\text { events/h }\end{array}$ & $\begin{array}{l}2.1 \\
\text { events/h }\end{array}$ & $\begin{array}{l}\text { Hadi et al., } \\
2012\end{array}$ \\
\hline 9 & T. obscurus & $\begin{array}{l}\text { Penang, } \\
\text { Malaysia }\end{array}$ & Disturbed forest reserve & $23.96 \%$ & $40.02 \%$ & $22.51 \%$ & $13.51 \%$ & $\begin{array}{l}\text { Md-Zain \& } \\
\text { Ch'ng, } 2011\end{array}$ \\
\hline 10 & T. obscurus & UKM, Malaysia & Disturbed forest reserve & $38.31 \%$ & $40.81 \%$ & $19.19 \%$ & $1.68 \%$ & $\begin{array}{l}\text { Ruslin et al., } \\
2014\end{array}$ \\
\hline 11 & T. p. poliocephalus & $\begin{array}{l}\text { Cat Ba Island, } \\
\text { Vietnam }\end{array}$ & $\begin{array}{l}\text { Natural island, national } \\
\text { park }\end{array}$ & $66 \%$ & $15 \%$ & $11 \%$ & $8 \%$ & $\begin{array}{l}\text { Schneider } e t \\
a l ., 2010\end{array}$ \\
\hline
\end{tabular}


Moving activities account for $26 \%$ of the daily activity budget and are nearly close as the percentage in the study on P. cinerea and T. obscurus, which are $25.8 \%$ and $22.51 \%$, respectively (Long et al., 2010; Md-Zain \& Ch'ng, 2011). Moving activities are related to multiple factors such as digestive physiology, ranging area, disturbance, threats, food abundance, weather, and population dynamics. Semi-habituated T. obscurus in Penang do not bother with human presence in the recreational area and thus can move freely (Md-Zain \& Ch'ng, 2011). However, N. larvatus is found to be the least moving (3.5\%) in Table 1 and seems to be related to its great resting time and the harem group comparably with our study where the focal group Dara is all-male band (Matsuda et al., 2009).

Social activities score the least in the daily activity budget of $P$. femoralis (5\%). They are adult all-male band thus the percentage seems to be similar in pattern as in the other studies. Though P. femoralis are ranging and moving in a group, social activities were very few to be recorded compared with other activities. One extreme percentage was shown by $P$. cinerea, where socialising made up of $25.1 \%$ of their daily activity budget (Long et al., 2010). $P$. cinerea in the study consist of a number of infants and juveniles where they mostly displayed playing, scrambling, and calling each other when the adults were feeding (Long et al., 2010). P. femoralis in our study also display playing behaviour between adult males and sympatricaly ranging $M$. fascicularis based on our observation.

The differences of daily activity budget of P. femoralis in this study did not vary much between seasons. Based on the result, during the fruiting season their activities comprised moving $(25 \%)$, feeding $(27 \%)$, resting $(42 \%)$, and socialising $(5 \%)$, whereas activities during the non-fruiting season comprised moving (28\%), feeding (20\%), resting (47\%), and socialising (5\%). Feeding behaviour of $P$. femoralis did reduce in the non-fruiting season maybe because of the availability of fruits in the ranging area, although this was statistically insignificant. The study area has a fruit orchard planted by villagers that provided high-calorie fruits such as durian (Durio zibenithus), rambutan (Nephelium lappaceum), banana (Musa acuminata $x$ balbisiana), jackfruit (Artocarpus heterophyllus), and mango (Mangifera indica). On top of that, two top commodity plants of Malaysia, which are rubber (Heveabrasiliensis) and oil palm (Elaeis guineensis), were also available in the study area and were consumed by $P$. femoralis.

Fruits are made up of simple sugars and have readily available nutrients (Harahap et al., 2012), thus it can reduce the resting activity for digestion in the fruiting season (42\%) compared with the non-fruiting season $(47 \%)$. However, the fruit eating activities did not vary significantly for the case of P. femoralis in $\mathrm{Kg}$. Johor Lama. Based on observations, there are several evergreen fruiting trees such as oil palm, rubber, and cempedak trees (Artocarpus integer) that offer fruits for P. femoralis. Although in non-fruiting seasons, $P$. femoralis are still able to consume fruits from evergreen fruiting trees as fallback food. Fallback foods are the resource of relatively low-preference foods that are used seasonally when preferred foods are unavailable (Marshall \& Wrangham, 2007). The behaviour of relying on fallback foods was also exhibited by other species of colobine monkeys. Maroon langur ( $P$. rubicunda), show the dependence on young leaves of Spatholobus macropterus (liana, Leguminosae) as fallback foods when the preferred foods are unavailable (Hanya \& Bernard, 2012). P. femoralis were recorded to consume evergreen fruiting trees such as rubber fruits $(H$. brasiliensis), oil palm fruits $(E$. guineensis), and banana fruits ( $M$. acuminata $x$ balbisiana) in the non-fruiting season. The non-fruiting season also indicated a higher percentage of moving to rationalise the need of travelling to search for high-calorie food. In conclusion, P. femoralis can adapt well to food availability to optimise their foraging strategy. 
Conservation and Human-Langur Conflict of P. femoralis

Comparing the data gained in this study with other langurs ranging in disturbed habitat, P. femoralis show that their daily activity budget was different from T. obscurus in Penang and UKM, Malaysia. Both cases show that feeding behaviour dominated the daily activity budget compared with $P$. femoralis in our study. P. femoralis showed resting activity budget as the main activity similar to $N$. larvatus in Sabah that ranged in natural riverine forest (Matsuda et al., 2009). This may indicate that P.femoralis has totally habituated with humans in the area as they behave normally like other colobines that lived in natural forest and intact forest (Schneider et al., 2010; Smith et al., 2013).

In contrast, $P$. femoralis did encounter conflicts with humans as they ranged inside the village and consumed fruits from the village orchard based on our observation on the field. For example, P.femoralis was found to consume mango ( $M$. indica) and banana ( $M$. acuminata $x$ balbisiana). As a result of this, we recorded a villager who aimed a slingshot and clapping hands to deter the $P$. femoralis, signifying it as pest. Pest behaviour may be directly related to the shrinking habitat size and conversion of forest into agriculture land such as oil palm plantation. Other instances such as human settlements, forest clearance, and human-primate conflicts are known as threats for the conservation of the species (Nijman et al., 2008). However, P. femoralis was found consuming an invasive species Mikania micrantha, that usually becomes a problem in disturbed habitat as its rapid spread becomes threats to both natural and agricultural environments, kills or reduces growth of preferred species, severely impacts biodiversity and agriculture production (Day et al., 2016). Another colobine monkey, capped langur (Trachypithecus pileatus) was also recorded to have largely consumed M. micrantha $(11.2 \%)$ from overall 43 species during winter in India (Solanki et al., 2008). Further studies may prove that the ecological function of P. femoralis in disturbed habitat is to control invasive species and balance out the notion of $P$. femoralis as solely pest. Opportunistic pest behaviour of the banded langur seen in Kg. Johor Lama is not naturally ignited but a behavioural drift due to multiple ecological and behavioural factors as for other colobines (Hill \& Wallace, 2012; Hill, 2017).

\section{Conclusion}

This study provides first systematic record of daily activity budget for P.femoralis in Malaysia, and based on their activity pattern, it was found to be fairly similar to other colobines. The daily activity budget displayed by $P$. femoralis gave an overview of population viability, which then can be applied into conservation and management effort. Further study should be focused on ranging behaviour, canopy use, terrestrial behaviour, and population dynamics to truly understand the behaviour of P. femoralis.

\section{Acknowledgements}

The authors would like to acknowledge Universiti Tun Hussein Onn Malaysia, Universiti Kebangsaan Malaysia and Department of Wildlife and National Parks (PERHILITAN) for providing necessary funding, facilities and assistance. This research was conducted under research permit (JPHL\&TN(IP):100-34/1.24 Jld 8) and was supported by Fundamental Research Grant Scheme FRGS/1/2018/ WAB13/UTHM/03/2 and Knowledge Transfer Programme Grant (KTP) KTP-PSH-2017 (LL(RI)-ECC/5 (UTHM-16)) provided by the Ministry of Education Malaysia, GPPSUTHM-U971-2017 by Universiti Tun Hussein Onn Malaysia (UTHM) and GUP-2019-037 by Universiti Kebangsaan Malaysia.

\section{References}

Abdul-Latiff, M. A. B., Aifat, N. R., Yaakop, S., \& Md-Zain, B. M. (2017a). A noninvasive molecular approach: Exploiting specieslocus-specific PCR primers in defeating numts and DNA cross-contamination of Cercopithecidae. Journal of Animal and Plant Sciences, 27(3), 1015-1023. 
Abdul-Latiff, M. A. B., Abdul-Patah, P., Yaakop, S., \& Md-Zain, B. M. (2017b). Aiding pest control management of longtailed macaques (Macaca fascicularis fascicularis) in Malaysia by using molecular markers of mitochondrial DNA. In: AIP Conference Proceedings, 1891(1), 020003-1-020003-6.

Abdul-Latiff, M. A. B., Baharuddin, H., AbdulPatah, P., \& Md-Zain, B. M. (2019a). Is Malaysia's banded langur, Presbytis femoralis femoralis, Presbytis neglectus neglectus? Taxonomic revision with new insights on the radiation history of the Presbytis species group in Southeast Asia. Primates, 60(1), 63-79.

Abdul-Latiff, M. A. B., Najmuddin, M. F., Haneef, S. K., Nabil, A., ShahroolAnuar, R., \& Md-Zain, B. M. (2019b). PrimaTourism: Preliminary study on activity budget of Presbytis neglectus with insights on local people perception on the product's potential economic value in Johor. In IOP Conference Series: Earth and Environmental Science, 269(1), P012006. IOP Publishing.

Abdul-Latiff, M. A. B., Najmuddin, M. F., Haneef, S. K., Nabil, A., Shahrool-Anuar, R., \& Md-Zain, B. M. (2019c). Transforming ranging behaviour of Schlegel's Banded Langur (Presbytis neglectus) into PrimaTourism product. In IOP Conference Series: Earth and Environmental Science, 269(1), 012005.

Allen, P., Bennett, K., \& Heritage, B. (2014). SPSS Statistics Version 22: A Practical Guide. Cengage Learning Australia.

Altmann, J. (1974). Observational study of behaviour: sampling methods. Behaviour, 49(3/4), 227-266.

Ang, A., Roesma, D. I., Nijman, V., Meier, R., \& Srivathsan, A. (2020). Faecal DNA to the rescue: Shotgun sequencing of non-invasive samples reveals two subspecies of Southeast Asian primates to be Critically Endangered species. Scientific Reports, 10(1), 1-16.

Caton, J.M. (1990). Structure and Function of the Catarrhine Stomach, with Particular Reference to the Colobinae. (Master's thesis). The Australian National University, Canberra, Australia.

Caton, J.M. (1999). Digestive strategy of the Asian colobine genus Trachypithecus. Primates, 40(2), 311-325.

Dar, M.E.I., Cochard, R., Shrestha, R. P., \& Ahmad, S. (2012). Floristic composition of Machiara National Park, District Muzaffarabad Azad Kashmir, Pakistan. International Journal of Biosciences, 2(4), 28-45.

Dasilva, G. L. (1993). Postural changes and behavioural thermoregulation in Colobus polykomos: the effect of climate and diet. African Journal of Ecology, 31(3), 226-241.

Day, M. D., Clements, D. R., Gile, C., Senaratne, W. K. A. D., Shen, S., Weston, L. A., \& Zhang, F. (2016). Biology and Impacts of Pacific Islands Invasive Species. 13. Mikania micrantha Kunth (Asteraceae). Pacific Science, 70(3), 257-285.

Fruth, B., \& McGrew, W. C. (1998). Resting and nesting in primates: behavioral ecology of inactivity. American Journal of Primatology, 46(1), 3-5.

Garber, P. A. (1987). Foraging strategies among living primates. Annual review of Anthropology, 16(1), 339-364.

Groves, C. (2001). Primate Taxonomy. Washington, DC: Smithsonian Institution Press.

Grueter, C. C., Li, D., Ren, B., \& Li, M. (2013). Overwintering strategy of Yunnan snub-nosed monkeys: adjustments in activity scheduling and foraging patterns. Primates, 54(2), 125-135.

Hadi, S., Ziegler, T., Waltert, M., Syamsuri, F., Mühlenberg, M., \& Hodges, J. K. (2012). Habitat use and trophic niche overlap 
of two sympatric colobines, Presbytis potenziani and Simias concolor, on Siberut Island, Indonesia. International Journal of Primatology, 33(1), 218-232.

Hambali, K., Ismail, A., \& Md-Zain, B. M. (2012). Daily activity budget of longtailed macaques (Macaca fascicularis) in Kuala Selangor Nature Park. International Journal of Basic \& Applied Sciences, 12, 47-52.

Hanya, G., \& Bernard, H. (2012). Fallback foods of red leaf monkeys (Presbytis rubicunda) in Danum Valley, Borneo. International Journal of Primatology, 33(2), 322-337.

Harahap, S. N., Ramli, N., Vafaei, N., \& Said, M. (2012). Physicochemical and nutritional composition of rambutan anak sekolah (Nephelium lappaceum L.) seed and seed oil. Pakistan Journal of Nutrition, 11(11), 1073-1077.

Hill, C. M. (2017). Primate crop feeding behavior, crop protection, and conservation. International Journal of Primatology, 38(2), 385-400.

Hill, C. M., \& Wallace, G. E. (2012). Crop protection and conflict mitigation: reducing the costs of living alongside non-human primates. Biodiversity and Conservation, 21, 2569-2587.

Khatun, M. T., Jaman, M. F., Rahman, M. M., \& Alam, M. M. (2018). The effect of urban and rural habitats on activity budgets of the endangered Northern Plains sacred langur, Semnopithecus entellus (Dufresne, 1797) in Jessore, Bangladesh. Mammalia, 82(5), 423-430.

Kirkpatrick, C. (2017). Asian Colobines. In The International Encyclopedia of Primatology (eds M. Bezanson, K.C. MacKinnon, E. Riley, C.J. Campbell, K. Nekaris, A. Estrada, A.F. Di Fiore, S. Ross, L.E. JonesEngel, B. Thierry, R.W. Sussman, C. Sanz, J. Loudon, S. Elton and A. Fuentes), 1-2.

Long, H. T., Tinh, N. T., Vy, T. H., \& Minh, H. T. (2010). Activity budget of grey-shanked douc langurs (Pygathrix cinerea) in Kon $\mathrm{Ka}$ Kinh National Park, Vietnam. Vietnamese Journal of Primatology, 4, 27-39.

Marshall, A. J., \& Wrangham, R. W. (2007). Evolutionary consequences of fallback foods. International Journal of Primatology, 28(6), 1219-1235.

Matsuda, I., Tuuga, A., \& Higashi, S. (2009). The feeding ecology and activity budget of proboscis monkeys. American Journal of Primatology: Official Journal of the American Society of Primatologists, 71(6), 478-492.

McCain, C. M. \& King, S. R. B. (2014). Body size and activity times mediate mammalian responses to climate change. Global Change Biology, 20, 1760-1769.

Md-Zain, B.M. (2004). Primat Taman Negeri Endau Rompin. In Shaharuddin Mohamad Ismail, Mokhtar Mat Isa, W. Yusoff W. Ahamd, M. Rahim Ramli\& A. Latiff (Eds). Taman Negeri Endau Rompin: Pengurusan, Persekitaran Fizikal dan Biologi. pg. 231236. Siri Kepelbagaian Biologi Hutan, Jabatan Perhutanan Semenanjung Malaysia.

Md-Zain B. M., Morales M. N., Hasan J. A., Lakim M., Supriatna J., Melnick D. J. (2008). Is Presbytis a distinct monophyletic genus: inferences from mitochondrial DNA sequences? Asian Primates Journal, 1, 2636.

Md-Zain, B. M., \& Ch'ng, C. E. (2011). The activity patterns of a group of Cantor's dusky leaf monkeys (Trachypithecus obscurus halonifer). International Journal of Zoological Research, 7(1), 59-67.

Md-Zain, B. M., Abdul-Manan, M. N., AbdulLatiff, M. A. B., Mohd-Daut, N., \& Rahman, A. (2019a). Positional behavior of robinson's banded langur (Presbytis femoralis robinsoni). Journal of Sustainability Science and Management, 14(5), 164-174.

Md-Zain, B. M., Abdul-Latiff, M. A. B., Rahman, A. (2019b). Taxonomy, population distribution and biogeography of Malaysian 
Primate [Public Lecture], $21^{\text {st }}$ August 2019, Kuala Lumpur, Malaysia. Unpublished.

Minhas, R. A., Khawaja, B. A., Awan, M. S., \& Iftikhar, N. (2010). Social Organization and Reproductive Biology of Himalayan Grey Langur (Semnopithecus entellus ajex) in Machiara National Park, Azad Kashmir (Pakistan). Pakistan journal of Zoology, 42(2), 143-156.

Najmuddin, M. F., Haris, H., Shahrool-Anuar, R., Norazlimi, N., Md-Zain, B. M., \& Abdul-Latiff, M. A. B. (2019a). Prima tourism: Plant selection by Schlegel's Banded Langur Presbytis neglectus in Johor. In IOP Conference Series: Earthand Environmental Science, 269(1), P012036. IOP Publishing.

Najmuddin, M. F., Haris, H., Norazlimi, N., Md-Zain, B. M., Mohd-Ridwan,

A. R., Shahrool-Anuar, R. Husna, H. A, \& Abdul-Latiff, M. A. B. (2019b). Predation of domestic dogs (Canis lupus familiaris) on Schlegel's Banded Langur (Presbytis neglectus) and Crested HawkEagle (Nisaetus cirrhatus) on Dusky Leaf Monkey (Trachypithecus obscurus) In Malaysia. Journal of Sustainability Science and Management, 14(6), 39-50.

Najmuddin, M. F., Haris, H., Nursyuhada, O., Fatin, Z., Md-Zain, B. M., Shahrool-Anuar, R., Ayeb, O., Othman, I. and Abdul-Latiff, M.A.B. (2020a). Data on First Record of Brown Morph Banded Langur (Presbytis femoralis), Leucistic Dusky Leaf Monkey (Trachypithecus obscurus) in Malaysia and Review of Morph Diversity in Langur (Colobinae). Data in Brief, 105727.

Najmuddin, M. F., Haris, H., Md-Zain, B. M., Mohd-Ridwan, A. R., \& Abdul-Latiff, M. A. B. (2020b). Population assessment of banded langur, Presbytis femoralis in Malaysia. Unpublished manuscript.

Nijboer, J. (2006). Fibre intake and faeces quality in leaf-eating primates (Doctoral dissertation). Utrecht University, Utrecht, Netherlands.
Nijboer, V. J., Clauss, M., Van de Put, K., Van der Kuilen, J., Woutersee, H., \& Beynen, A. C. (2007). Influence of two different diets on fluid and particle retention time Javan langur (Trachypithecus auratus auratus). Der Zoologische Garten, 77(1), 36-46.

Nijman, V., Geissman, T. \& Meijaard,

E. (2008). Presbytis femoralis. The IUCN Red List of Threatened Species 2008: e.T18126A7665311.

Othman, F., \& Amin, N. F. M. (2018). Generation of flood map using info works for Sungai Johor. International Journal of Integrated Engineering, 10(2), 142-145.

Reed, J. M. (2002). Animal Behavior as a Tool in Conservation Biology In: A. A. Aguirre, R. S. Ostfeld, C. A. House, G. M. Tabor, \& M. C. Pearl (Eds.) Conservation Medicine: Ecological Health in Practice (pp. 145163). Oxford University Press.

Rizzuto, M., Carbone, C., \& Pawar, S. (2017). Foraging constraints reverse the scaling of activity time in carnivores. Nature Ecology \& Evolution, 2(2), 247-253.

Ruslin, F., Matsuda, I., \& Md-Zain, B. M. (2019). The feeding ecology and dietary overlap in two sympatric primate species, the longtailed macaque (Macaca fascicularis) and dusky langur (Trachypithecus obscurus obscurus), in Malaysia. Primates, 60(1), 41-50.

Ruslin, F., Yaakop, S., \& Zain, B. M. M. (2014). A preliminary study on activity budget, daily travel distance and feeding behaviour of long-tailed macaques and spectacled dusky leaf monkey in Bangi campus of Universiti Kebangsaan Malaysia, Selangor. AIP Conference Proceedings 1614(1), 688-692.

Schneider, I., Tielen, I. H., Rode, J., Levelink, P., \& Schrudde, D. (2010). Behavioral observations and notes on the vertical ranging pattern of the critically endangered Cat $\mathrm{Ba}$ langur (Trachypithecus poliocephalus poliocephalus) in Vietnam. Primate Conservation, 2010(25), 111-118. 
Sha, J. C. M., Chua, S. C., Chew, P. T., Ibrahim, H., Lua, H. K., Fung, T. K., \& Zhang, P. (2018). Small-scale variability in a mosaic tropical rainforest influences habitat use of long-tailed macaques. Primates, 59(2), 163-171.

Siti-Kauthar, M., Najmuddin, M. F., Md-Zain, B. M., \& Abdul-Latiff, M. A. B. (2019). PrimaTourism: Preliminary Study on Activity Budget of Dusky leaf monkey Trachypithecus obscurus obscurus in Bukit Soga Perdana, Batu Pahat, Johor. In IOP Conference Series: Earth and Environmental Science, 269(1), P012045. IOP Publishing.

Smith, D. A. E., Smith, Y. C. E., \& Cheyne, S. M. (2013). Home-range use and activity patterns of the red langur (Presbytis rubicunda) in Sabangau tropical peatswamp forest, central Kalimantan, Indonesian Borneo. International Journal of Primatology, 34(5), 957-972.
Solanki, G. S., Kumar, A., \& Sharma, B. K. (2008). Winter food selection and diet composition of capped langur (Trachypithecus pileatus) in Arunachal Pradesh, India. Tropical ecology, 49(2), 157.

Tinbergen, N. (1963). On aims and methods of ethology. Zeitschrift für tierpsychologie, 20(4), 410-433.

Vun, V.F., Mahani, M. C., Lakim, M., Ampeng, A., \& Md-Zain, B. M. (2011). Phylogenetic relationships of leaf monkeys (Presbytis; Colobinae) based on cytochrome $b$ and 12S rRNA genes. Genetic and Molecular Research, 10(1), 368-381.

Yap, J. L., Ruppert, N., \& Rosely, N. F. N. (2019). Activities, habitat use and diet of wild dusky langurs. Journal of Sustainability Science and Management, 14(4), 71-85. 